\title{
Citizenship Regimes and the Politicization of Immigrant Groups
}

\author{
Didier Ruedin ${ }^{1, *}$ \\ 1 University of Neuchâtel, Switzerland; University of the Witwatersrand, Johannesburg, South Africa \\ * E-Mail: didier.ruedin@unine.ch
}

\begin{abstract}
Previous research has examined the various ways individuals and organizations react to immigration. This article explores how immigrants and their integration are debated across citizenship regimes, with a focus on 'voiceless' groups without formal franchise and a precarious residence status: asylum seekers, refugees, and irregular immigrants. A yearly measure of citizenship regimes is used together with a large-scale claims analysis of newspapers from seven Western European countries between 1995 and 2009 to systematically describe the relative frequency of and frames in different claims by political actors. The debate on immigration and integration varies by citizenship regime, including the way immigrant groups are referred to. Having an ethnic citizenship regime is associated with more claims about voiceless immigrant groups. At the same time, the association between immigrant group size and the extent to which immigrant groups are politicized is moderated by the citizenship regime. Debates on immigrants and their integration vary across citizenship regimes.
\end{abstract}

\section{Keywords}

Immigration, ethnicity, politicization, citizenship regime, framing, salience, claims analysis

\section{Staatsangehörigkeitsregime und die Politisierung von Immigranten}

\section{Zusammenfassung}

Dieser Artikel untersucht, wie Migranten und deren Integration in verschiedenen Staatsangehörigkeitsregimes diskutiert werden, wobei der Fokus auf „stimmlosen“ Gruppen ohne formalem Wahlrecht und einem prekären Aufenthaltsstatus liegt: Asylbewerber, Flüchtlinge und illegale Einwanderer. Jährliche Werte von Staatsangehörigkeitsregimes werden zusammen mit einer groß angelegten Claims-Analyse verwendet, um systematisch die Frames verschiedener politischer Akteure zu beschreiben. Debatten über Einwanderung und Integration variieren je nach Staatsangehörigkeitsregime. In ethnischen Staatsangehörigkeitsregimes werden mehr Claims über stimmlose Einwanderergruppen beobachtet. Gleichzeitig wird der Zusammenhang zwischen der Größe von Migrantengruppen und dem Ausmaß, in dem diese Migrantengruppen politisiert werden, vom Staatsangehörigkeitsregime moderiert.

\section{Schlüsselwörter}

Einwanderung, Ethnizität, Politisierung, Staatsangehörigkeitsregime, Framing, Salienz, Claims-Analyse

\section{Acknowledgements}

I would like to thank Sieglinde Rosenberger for her contributions to an earlier version of this article including the notion of voiceless groups, and the anonymous reviewer, Jeremias Stadlmair, Astrid Mattes, Irene Bloemraad, Erik Bleich, Sarah Meyer, Teresa Peintinger, Jean-Thomas Arrighi de Casanova, Marco Guigni, Oliver Strijbis, and William Doehler for comments and suggestions. This work was supported by the European Commission's Seventh Framework Programme (FP7/2007-2013) [grant number 225522], and by the Swiss National Science Foundation [grant number I4I55I].

The author has declared that no competing interests exist. 


\section{Introduction}

In most Western societies, immigration and immigrant integration figure prominently in political debates. Politicians and public narratives alike have linked the growing number and diversity of immigrants in Western societies with topics as far-ranging as pressure on the welfare state, growing competition in the labour market, challenges to key social values and national identities, or a decline in social capital (Vasta 20IO; Goldin et al. 20II; Kymlicka 20II). Within this context of contestation, immigrant groups are referred to in different ways, reflecting legal status, national communities, and religious affiliation. In the realm of politics, however, the presence, citizenship rights, economic achievements, culture and identities of only some immigrant groups are controversial, while other groups are hardly mentioned in debates (Korkut et al. 20I3). There are striking differences across time and countries with regard to which groups are politicized, and how they are referred to in political debates (Koopmans et al. 2005; Van der Brug et al. 2015). For example, the application of racial categories is almost exclusive to Anglo-Saxon countries, while moral categorization and the politicization of Muslims have increased across most Western countries in recent years (Brubaker 2013; Berkhout/Ruedin 2016).

These dynamics in politicization reflect a contestation of immigration, which entails both legal frameworks and the discursive construction and maintenance of in- and out-groups. This construction not only concerns boundaries between immigrants and non-immigrants but also between different immigrant categories (Brubaker 20I3). This legal, ethnic, racial, national and religious boundary-making is reflected in political claims about the distribution of rights and goods. In-groups enjoy undisputed access to rights and goods, while out-groups must justify such access. These claims, in turn, follow competing definitions of citizenship, membership and belonging within culturally diversified but territorially bounded societies. Hence, in political debates immigrant groups are discussed not only with reference to their (legal/administrative) residence status but also their national or ethnic origin, or race and religion (Van der Brug et al. 2015). Groups do not simply exist in legal terms but they are constructed, questioned and maintained within political debates in general, and claimsmaking processes in particular. The immigrant groups that can be observed are the temporary outcomes of these processes of boundary-making.

The media play an important role in shaping the politicization of immigrant groups and how they are constructed in debates. They inform both the public and political actors, and influence which issues are regarded as pressing. Even as major print media are read less, they remain dominant in setting the debate (Bleich et al. 2015; Lawlor 2015). It is important to bear in mind, however, that the media are not a monolithic construct, but reflect many different voices - including those of immigrants. As such, media coverage includes different tones and arguments, and differences across countries and time should be expected (Bleich et al. 2015; Van der Brug et al. 2015). It is through these different ways of how immigrant groups are mentioned in the media that they are constructed (Caviedes 2015; Lawlor 2015): Immigrant groups are actively constituted in claims-making. For example, when a claim refers to immigrants by nationality, this often reflects an implicit choice: The actor could have identified the same person in terms of legal status, or religion, for instance. Claims-making is understood as in Koopmans et al. (2005) and refers to individual instances of public claims that are reported in national newspapers. A claim is the purposive "articulation of political demands, calls to action, proposals, criticisms, or physical attacks, which, actually or potentially, affect the interest or integrity" of immigrant groups (ebd., 252).

This article examines the politicization of immigrant groups in seven European countries - Austria, Belgium, Ireland, the Netherlands, Spain, Switzerland, and the United Kingdom. The choice of countries provides variation in the number of immigrants, and historical differences in when large numbers of immigrants started to arrive. Throughout the article, attention is paid to different citizenship regimes in a detailed manner to explore their role in the politicization of immigration. It is shown that the politicization of immigrant groups varies by citizenship regime. This is done with regard to so-called voiceless groups, an analytical category introduced to better capture the role of citizenship regimes. Voiceless groups are defined in administrative terms that limit their means to directly participate in political debates, and they have to rely on other actors to give them a voice in debates. There is more frequent politicization of voiceless groups in ethnic contexts. Irrespective of the citizenship regime, normative principles are mentioned more often when it comes to voiceless groups, but the citizenship regime is associated with how group size in the population is translated into politicization.

\section{Differences in the Politicization of Immigrant Groups: Theory and Expectations}

In this article, politicization describes the fact that in political debates actors make references to and claims about certain groups and policies regulating these groups. De Wilde (2007) highlights that first a topic is put on the public agenda, and then polarized to become relevant in political debate, leading to policies being formulated and discussed publicly. A topic or 
group is therefore more politicized when there are more claims about the topic or group: They are on the political agenda and appear in debates. Of interest is in particular the extent to which different immigrant groups are politicized in relation to each other. By focusing on relative frequency, the importance of immigration as a topic overall is largely controlled away by design. The literature offers different theoretical perspectives with competing expectations on why and how the politicization of immigrant groups varies across countries and over time: (I) the size and visibility of immigrant groups, (2) the possibility of immigrant groups to participate in debates themselves (e.g. Finotelli/Michalowski 2012), and (3) immigration policy and citizenship regimes.

To begin with group size and visibility, a basic premise is that there is a direct relationship between the demographic composition of the immigrant population and the debate on immigration (see discussions in Van der Brug et al. 2015). In particular immigrants perceived as culturally different are regarded as a greater economic, political, or symbolic threat than immigrants who belong to groups perceived as 'nears' and 'dears' (Tholen 2009), especially when there are many of them. To counter such threats, they tend to be opposed and politicized in a negative way: Political actors make claims about these groups. Purportedly, more visible groups are politicized more frequently and in more negative or polarized terms. While this article will examine the relationship between politicization and group size, there is empirical work questioning a direct relationship between group size and politicization. For instance, immigrants from other Western European countries are rarely politicized across Europe, while there are many claims about Muslim immigrants who constitute a much smaller immigrant group (Van der Brug et al. 2015). Similar to Bloemraad, Graauw, and Hamlin (2015), the contributions in Van der Brug et al. find no evidence that immigrant group size is directly related to politicization (see also Klingeren et al. 2015; Berkhout/ Ruedin 2016).

The second explanation concerns the possibility of immigrant groups to participate in debates themselves. The analytical category of voiceless groups is introduced to better understand how the politicization of immigration varies by citizenship regime. These are namely asylum seekers, refugees, and irregular immigrants: immigrant groups not only characterized by their lack of access to formal politics, but also by a precarious residence and social status (Gibney 2009). They are 'voiceless' in the sense that they are usually unable to speak for themselves in political debates (Bleich et al. 2015). With few resources and a reluctance to appear in public (Ruedin et al. 2017), they typically rely on others to 'defend' their interests in debates, notably NGO and civil society actors (Rosenberger/Ruedin 2017) or neighbours. By con- trast, immigrants with stable residence rights typically have resources, organizations, and access to participate directly. As vulnerable groups, voiceless groups are also less likely to participate in protests themselves, and for that reason it can be assumed that political actors are less constrained in the way they can address these groups in political claims (see further discussion in Cağlar/Mehling 2013; Beckman 2013).

Of the voiceless groups, asylum seekers play an important role, both numerically and because the policies in place usually ensure they remain in a precarious situation. For instance, asylum seekers are often denied the possibility to engage in paid work or are placed in special centres (Schuster 2003; Squire 2009). These policies have the effect that asylum seekers are less likely than other immigrant groups to be organized in any form. By contrast, 'voiceful' groups like EU-citizens enjoy limited political rights but full economic and residency rights. This restricts the manner in which these groups can be addressed in public debate. The focus on voiceless groups allows a clearer analysis of the role of citizenship regimes in politicization by reducing or excluding the influence of the other factors outlined. Voiceless groups are an analytical category to ensure that the groups under consideration have equivalent rights: in this case none to formal politics.

With a focus on being voiceless, particular actor-object constellations may influence politicization. Specific to voiceless groups is that these groups are in positions in which they are unlikely to have the same kind of access to public claims-making than other groups in society. Characterized by an absence of rights and franchise, as well as having low status, they are thus less able to fend for their own interests, leaving them vulnerable to negative claims by other actors - particularly actors seeking to further their own agenda by 'othering' another group. It is the lack of political means to counter negative politicization directly that renders these groups voiceless. Indeed, attitudes to these groups tend to be more negative than to other groups (Constant et al. 2009). It follows that claims about voiceless groups are more likely to be negative in tone.

At the same time, because of their marginalized position, voiceless groups are likely to be supported by certain actors - namely actors from the political left as well as religious and civil-society organizations as traditional champions of minorities and the weak (Giugni/ Passy 200I; Rosenberger/Ruedin 20I7). Voiceless groups might get sympathy because of their vulnerable position (Coenders et al. 2013). With the support of these actors, be they left-wing parties or civil-society organizations, voiceless groups appear in public claims-making in a positive way. Put differently, claims about voiceless groups by civil-society actors are more likely to be positive. Combined with the more negative claims by other actors, this 
probably leads to an increased polarization of positions when it comes to voiceless groups. Given their vulnerable position, voiceless groups can be perceived as (potential) burdens to the welfare state and thus are likely to be confronted with negative reactions. Such groups tend to be 'othered' and singled out in public debates, and it can be expected that the kind of justification in claims is affected (Helbling 20I4). As is common in the literature, we can draw on a distinction between instrumental, normative, and identity frames. Claims drawing on normative principles justify policy change with reference to principles like equality or human rights; references to identity span national identities, cultural and institutional traditions, as well as values. These frames are contrasted with instrumental frames that involve some kind of cost-benefit calculation, like references to economic benefits (Van der Brug et al. 2015). We can expect that claims about voiceless groups are more likely to use frames drawing on normative principles and identities than claims about other groups.

A third explanation for the politicization of immigrant groups concerns immigration policy and citizenship regimes. Faced with the challenges brought about by increasing levels of immigration and an increasingly diverse immigrant population there are different policy responses (Zincone et al. 20II). In broad lines, these differences can be captured in citizenship regimes: the jurisdiction and legal practices in place. Citizenship regimes also reflect how citizenship and national belonging are perceived in a country in general, and to some extent the immigration and immigrant integration policies in place reflect conceptions of citizenship. Following Koopmans et al. (2005) citizenship regimes can be defined along two axes: On the one hand, ethnic and civic citizenship regimes, and on the other cultural monism and pluralism are contrasted (see Vink/Bauböck 2013 for a discussion of alternative conceptualizations).

The ethnic-civic dimension looks at access to citizenship, distinguishing between an ethnic and civic-territorial understanding of citizenship. This legal dimension looks at how immigrants acquire rights and nationality to become full members of society. The cultural monismpluralism dimension captures the regulation of cultural difference and group rights. This cultural dimension looks at the support of cultural and religious minority groups of immigrant origin, irrespective of nationality. While there are strong traditions in the way citizenship policies are implemented in different countries, this article takes into consideration that citizenship regimes are dynamic to some degree, and there are changes over time (Ersanilli/Koopmans 20II; Ruedin 2015; Koopmans/Michalowski 20I7). By considering changes over time, this article provides variance to differentiate the influence of citizenship regimes from that of different immigrant populations, which also vary by country (see Appendix AI for mean citizenship scores and their range).

Given the way citizenship regimes reflect different conceptions of national belonging, it can be expected that they not only account for differences in politicization across countries, but also for differences between groups and how they are referred to in claims. The citizenship regime can be regarded as bounds to the way specific immigrant groups are politicized by actors and how claims are justified with particular frames: Depending on the context, some claims will find resonance, or almost be taboo - like the use of racial categories in many European countries. In particular, it is assumed that both the ethnic-civic and the monistic-pluralistic dimension reflect which groups are politicized, or how immigrants are referred to.

Helbling (2014) looked at frames used by political parties in five Western European countries and concluded that citizenship regimes are largely unrelated to the frames used in the debate on immigration, that is, the way claims about different immigrant groups are justified by parties. Taking a broader view and considering all kinds of political actors, we can still expect that the frames used in claims are likely to vary according to the citizenship regime in place, especially if citizenship regimes are considered as tendencies rather than fixed categories. Depending on the citizenship regime - where on the two scales introduced by Koopmans et al. (2005) the policies are situated -, some justifications might be more successful in debates than others, and actors are more likely to turn to them. Specifically, because in ethnic contexts the notion of ethnicity is more salient, one might expect that instrumental justifications are more common in civic contexts, while in ethnic contexts identity arguments are more common.

Koopmans et al. (2005) highlight that different conceptions of citizenship affect the way immigrant groups are politicized. The different actors involved in claimsmaking are embedded in the same national context that reflects a particular citizenship concept, and this article argues that this constrains them with regard to the manner and extent to which different immigrant groups can be politicized. The intuition is that immigration is generally used to demarcate the boundary between ingroups ('us') and out-groups ('them'). We can expect the ethnic-civic dimension to be associated with which specific immigrant groups are more likely to be politicized or how they are constructed in public claims. The intuition is that in ethnic contexts highlighting the legal situation as a non-citizen suffices to emphasize difference from an immigrant group. In a civic context, by contrast, the legal status of why an immigrant is present has less currency to identify outsiders, and non-administrative categories like the country of origin or religion are more likely to be evoked. Given that voiceless groups are de- 
fined by their legal-administrative status, it can be expected that in ethnic contexts there are relatively more claims about voiceless groups. Similarly, in pluralistic contexts diversity is accepted and valued, meaning that immigrants can be referred to in many different ways to distinguish them from the majority population. References to religion or country of origin therefore are just as likely as references to administrative categories. In monistic contexts, by contrast, emphasizing difference other than in terms of administrative categories has less currency in public debates, and we can expect more references to generic signifiers like 'immigrant' or administrative categories more generally. It can therefore be expected that in monistic contexts the share of claims about voiceless immigrant groups is higher.

\section{Data and Methods}

This article draws on a large-scale media analysis, covering newspapers in seven European countries from I995 to 2009. For a random selection of 700 days, and for each country's dominant linguistic groups, all articles on immigration and integration in two national newspapers were sampled by manually checking all articles in the newspapers. This led to over 7,000 articles from both broadsheet and tabloid newspapers coded manually according to a common codebook (Van der Brug et al. 2015, see appendix A2 for a list of newspapers). The analysis counts instances where the groups, claimants and frames are within the realm of politics. The unit of analysis is a particular claim about immigration. Specifically, a claim exists when a political actor - defined in the broadest sense - makes a statement that suggests some aspect of policy is to be changed. Each claim can be positive or negative - its tone -, and uses a certain justification - its frame. Different dimensions of politicization are captured using the share of claims about specific immigrant groups, and by the frames and the tone of the claims. These aspects of politicization constitute the outcome variables, so to speak.

Frames describe how a claim is presented or justified in newspapers, differentiating instrumental frames, identity frames, and frames drawing on moral principles. An anti-immigrant group may oppose immigrants from Eastern Europe as they are regarded as unwelcome competition in the labour market. This justification is economic and refers to an instrumental frame. A civil-society organization, by contrast, may emphasize human rights when discussing asylum seekers from a politically unstable country. In this case normative principles are invoked (see appendix $\mathrm{A}_{3}$ for details, and Helbling (2OI4) for an equivalent classification). The tone of the claim captures whether the claim would have a positive or negative impact on an immi- grant group, using 5 response categories. Claims with a positive tone are open towards immigrants, progressive, or multi-cultural; negative claims are restrictive to immigrants, conservative, indicate preference for national citizens, or are mono-cultural (Van der Brug et al. 2015). The combination of how groups are debated in claims, the tone of the message, and the frame used leads to an active constitution of immigrant groups by political actors (Krzyżanowski/Wodak 2009).

As predictor variables, the kind of political actor, and citizenship regimes are considered. Actors were classified according to their function during coding. Of interest in this article are civil-society organizations, left-wing parties, and anti-immigrant organizations (including anti-immigrant parties because there are too few claims by anti-immigrant parties to treat them separately - see Meyer and Rosenberger (2015) on the misconception that anti-immigrant parties make most claims on immigrants; see appendix A4 for party classifications), while all other actors are combined in a residual category. Civil-society organizations comprise different kinds of organizations, including non-governmental organizations (NGO) and religious organizations, but exclude anti-immigrant organizations. In the basic operationalization immigrant organizations are counted separately, in a separate one they are included as civil-society organizations, leading to the same substantive results.

Citizenship regimes are conceived as outlined in Koopmans et al. (2005), and operationalized by recomposing extended MIPEX data to capture year-on-year changes in policy (Ruedin 2013; see Huddleston/Niessen 201 I for a description of the MIPEX data). Ruedin (2015) demonstrates that this approach closely matches data presented by Koopmans, Michalowski, and Waibel (2012). The MIPEX data contain indicators that - when re-assembled - capture the two dimensions well (see Ruedin 2015 for an extended discussion). ${ }^{.}$There is substantive variation across countries and time (compare Appendix AI). As a result, citizenship scores are available for every year and country, and the article refers to contexts because tendencies rather than fixed regimes are captured.

Bivariate analysis and an OLS regression model are used to describe the relationship between citizenship regimes and the politicization of immigration. In some

I For the ethnic-civic dimension, the following MIPEX items were used: eligibility for long-term residence, formal rights regarding political participation, informal rights regarding political participation, eligibility for nationality, security of nationality status, dual nationality, and anti-discrimination. The monism-pluralism dimension includes the following MIPEX items: integration measures for labour-market access, consultative bodies as political participation, implementation policies regarding political participation, cultural requirements for family reunion, cultural requirements for long-term residence, and cultural requirements for naturalization. 
of the tables, citizenship regimes are dichotomized by dividing scores at 50 , the mid-point. At this aggregated level, too, there is variance within countries. In the regression model, the outcome variable is the proportion of claims about voiceless groups in a given country-year, and predictor variables are the proportion of asylum seekers, and the citizenship regime (monisticpluralistic).

\section{Results}

\section{Politicization of Voiceless Groups}

In a first step, it is established that larger groups are not more politicized than smaller groups. The most common way to refer to immigrants in claims is in the generic sense, simply as immigrants, foreigners or foreign citizens without further qualification. This can be interpreted as the politicization of immigrants as non-citizens. Table I shows the proportion of claims about a selection of immigrant groups alongside their size in the general population. It is apparent that the size of immigrant groups is not directly associated with their politicization, both when comparing within countries and across countries. Consider for instance the fact that the majority of claims recorded in Ireland concern asylum seekers, despite their small share in the population, or claims in Austria where asylum applications decreased from nearly 40,000 in 2002 to fewer than 13,000 in 2009, while the proportion of claims about asylum seekers increased. There are no statistically significant correlations between group size and claims in the news across countries $(\mathrm{p}>0 . \mathrm{I}$ for all three groups considered in Table I).

Table 1: Claims and Immigrant Group Size

\begin{tabular}{lllllll}
\hline & $\begin{array}{l}\text { Muslims } \\
\text { Popu- } \\
\text { lation }\end{array}$ & Claims & $\begin{array}{l}\text { EU-15 } \\
\text { Popu- }\end{array}$ & & \multicolumn{3}{c}{$\begin{array}{c}\text { Asylum Seekers } \\
\text { lation }\end{array}$} & Claims & $\begin{array}{l}\text { lation } \\
\text { latia }\end{array}$ & Claims \\
\hline Austria & $4 \%$ & $9 \%$ & $3 \%$ & $1 \%$ & $0.5 \%$ & $31 \%$ \\
Belgium & $3 \%$ & $12 \%$ & $6 \%$ & $1 \%$ & $0.9 \%$ & $12 \%$ \\
Ireland & $1 \%$ & $1 \%$ & $7 \%$ & $0.3 \%$ & $0.1 \%$ & $58 \%$ \\
Netherlands & $4 \%$ & $12 \%$ & $2 \%$ & $0.4 \%$ & $0.1 \%$ & $20 \%$ \\
Spain & $2 \%$ & $3 \%$ & $2 \%$ & $0.2 \%$ & $0.01 \%$ & $1 \%$ \\
Switzerland & $2 \%$ & $14 \%$ & $9 \%$ & $5 \%$ & $0.6 \%$ & $26 \%$ \\
$\begin{array}{l}\text { United } \\
\text { Kingdom }\end{array}$ & $2 \%$ & $13 \%$ & $2 \%$ & $2 \%$ & $0.1 \%$ & $20 \%$ \\
\hline
\end{tabular}

Notes: all years are combined for the claims data, I00\% refers to all claims on immigration and integration in a country; population as of 2005 , foreignborn (Morales et al. 2012)
At the same time, in contexts with a larger proportion of Muslim immigrants, there are fewer claims about voiceless groups, among which asylum seekers are an important part $(\mathrm{r}=-0.26, \mathrm{p}<\mathrm{O} . \mathrm{OI})$. This suggests that voiceless groups are politically marginalized and singled out for being different - as assumed -, but in contexts with a larger Muslim population, another immigrant group Muslims - seems to play this role. By contrast, immigrants from EU-I5 countries are hardly politicized, despite their large share in the population. Indeed, EU/ EFTA citizens, immigrants from former colonies, family reunifications, or religious immigrant groups other than Muslims tend to be rarely politicized (Van der Brug et al. 2OI5).

For a better understanding of the politicization of immigrant groups, it is constructive to look the tone of claims, not just the volume. Because the tone of claims is measured on a categorical rating scale (5-points), interpolated median values are used as central tendencies (Revelle 2015). There is no statistically significant difference in tone between claims about voiceless groups and those about other immigrant groups (p>0.I). The expectation that voiceless groups are generally politicized in more negative terms cannot be supported.

This analysis, however, may hide differences due to particular actor-object constellations. To this end Figure I presents the tone of claims about voiceless groups and other immigrant groups by actor type. The figure gives kernel densities to show the distribution of tones for each constellation of interest. In each case the thick black line gives the interpolated median as a measure of central tendency, and the zero line (dashed) for reference. The first row in the figure highlights that the tone of claims about voiceless groups tends to be similar to other immigrant groups, perhaps slightly less positive. By contrast, irrespective of immigrant group, civil-society actors and left-wing parties tend to make more positive claims about immigrants. In particular for civil-society organizations it is rare to make negative claims, visible by the thin tail on the left. This near absence of negative claims is particularly pronounced when it comes to voiceless groups $(p<0.0 I)$ - and cannot be found for corresponding claims by left-wing parties. Taken together, the figure provides clear evidence against the expectation that voiceless groups are generally politicized in more negative terms. At the same time, civil-society organizations and left-wing parties are more likely to make positive claims about voiceless groups than other actors, but this is a reflection of their more positive stance on immigrants more generally. 
Figure 1: Tone of Claim by Immigrant Group and Actor
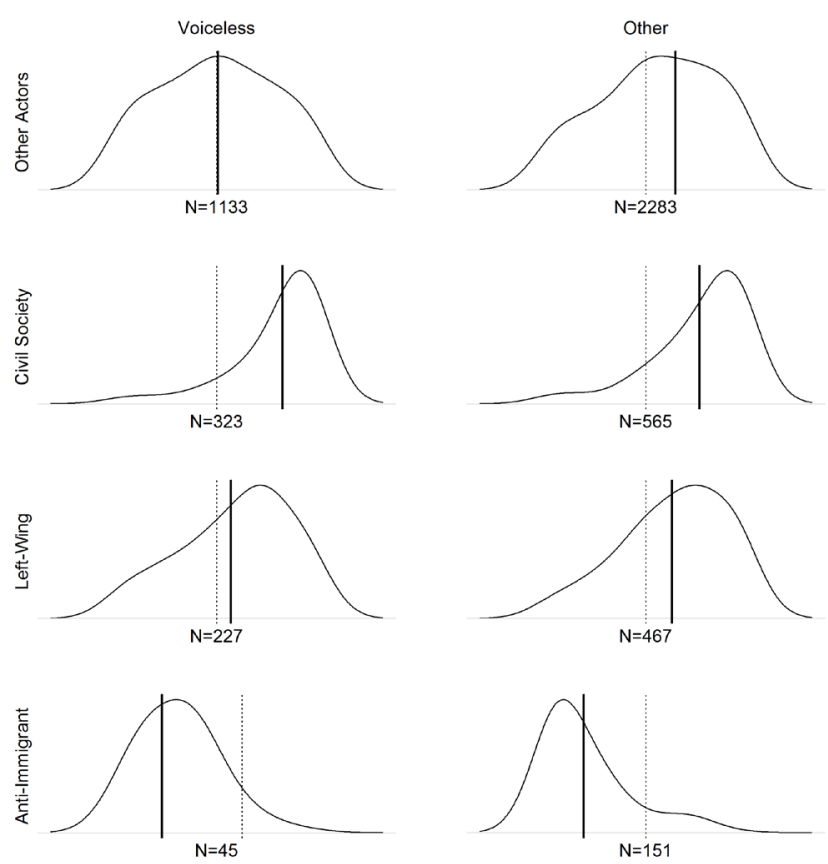

Notes: This figure gives the kernel distributions of the tone of claims, divided by the actor making the claim (vertical) and whether the claim was made about voiceless groups (horizontal). In each instance, negative claims are on the left; the number in each case indicates the number of claims recorded. The black lines give the interpolated median as a measure of central tendency, the dashed lines indicate zero (neutral tone).

Claims can be positive or negative about immigrants, but they also tend to use a particular frame, that is a justification as to why the claimant believes things should change, presenting the claim in a particular light. Frames may invoke normative principles like ideas of equality, human rights or solidarity; frames may be instrumental in that they underline pragmatic and utilitarian considerations, and there are identity frames. In all countries instrumental frames are dominant - both for voiceless and other groups. Identity frames are far less common for voiceless groups than for other immigrant groups, and normative principles are invoked more often in claims about voiceless groups than in claims about other immigrant groups (Table 2, $\mathrm{p}<\mathrm{O} .00 \mathrm{I})$. The fact that claims about voiceless groups are more likely to invoke normative principles may be a reflection of the sympathies that asylum seekers and in particular refugees may get because they are often seen as vulnerable groups in need of protection (Coenders et al. 2013). ${ }^{2}$

2 Using the data at hand, I find no support for Park's (2OI4) suggestion that human rights frames, included in the table under the heading moral principles, would be more common in countries that were widely regarded as emigration countries until recently - in the present case Ireland and Spain.
Table 2: Justification (Frames) in Claims about Voiceless Groups

\begin{tabular}{llll}
\hline Group & Instrumental & Identity & Moral Principles \\
\hline Voiceless & $62 \%$ & $2 \%$ & $36 \%$ \\
Other & $55 \%$ & $16 \%$ & $28 \%$ \\
\hline
\end{tabular}

\section{The Role of Citizenship Regimes}

A central claim of this article is that the politicization of immigration varies by citizenship regime. Focusing on the nature of claims, we can expect more use of instrumental frames in contexts characterized by a civic regime, and more use of identity frames in ethnic contexts. Table 3 illustrates that these intuitions bear out empirically. As in the table that follows, the citizenship regime of a country and year is reduced to a binary contrast, considering the difference between contexts below the theoretical midpoint and those above. In line with the expectation and as an extension to Table 2, we observe that claims in civic contexts are considerably more likely to draw on instrumental justifications ( $\mathrm{p}<\mathrm{O} . \mathrm{OI})$. By contrast, in more ethnic contexts, identity arguments are evoked more often.

Table 3: Frames by Citizenship Regime

\begin{tabular}{llll}
\hline & Instrumental & Identity & Moral Principles \\
\hline Civic & $63 \%$ & $8 \%$ & $29 \%$ \\
Ethnic & $55 \%$ & $16 \%$ & $29 \%$ \\
\hline
\end{tabular}

Notes: citizenship scores were cut at the theoretical midpoint; given are the percentages of all claims by frame

As Table 4 illustrates, the citizenship regime is also associated with the politicization of voiceless immigrant groups in particular. In line with the expectations, there are relatively more claims about voiceless groups in ethnic and monistic contexts $(\mathrm{p}<\mathrm{O} . \mathrm{OI})$. This is visible by the percentage points in the table: The first two rows contrast ethnic and civic contexts $(36 \%>29 \%)$; the last two rows contrast monistic and pluralistic contexts $(34 \%>$ 31\%). This association between citizenship regime and the politicization of voiceless groups can also be observed when the scores are not reduced to the binary contrast as is done in Table 4: There is a positive correlation between scores indicating citizenship regimes being more ethnic and the proportion of claims about voiceless groups $(\mathrm{r}=0.34, \mathrm{p}<\mathrm{O} . \mathrm{OOI})$, as well as a somewhat weaker association between scores indicating citizenship regimes being more monistic and the proportion of claims about voiceless groups $(r=0.18, p<$ O.I). Put 
differently, differences in the conception of citizenship are not only associated with the way immigrant groups are addressed in political claims, but also with the extent to which different groups are politicized, or how immigrants are referred to in claims.

Table 4: Claims about Voiceless Immigrant Groups by Citizenship Regime

\begin{tabular}{lll}
\hline & Other & Voiceless \\
\hline Ethnic & $64 \%$ & $36 \%$ \\
Civic & $71 \%$ & $29 \%$ \\
Monism & $66 \%$ & $34 \%$ \\
Pluralism & $69 \%$ & $31 \%$ \\
\hline
\end{tabular}

Notes: citizenship scores were cut at the theoretical midpoint; given are the percentages of all claims by citizenship regime

In a final analysis I examine whether the citizenship regime is associated with the way group size in the population is translated into politicization. The share of asylum seekers in the population is used as a proxy of the share of voiceless groups. While there are no more claims about voiceless groups in contexts where the share of asylum seekers is larger - see Table I above -, Figure 2 indicates that this relationship is shaped by the citizenship regime. Here a simple OLS regression model is used with the proportion of claims about voiceless groups measured per country and year - as the outcome variable, and the proportion of asylum seekers in the population, and the citizenship regime (monistic-pluralistic) as predictor variables. The figure presents the statistical interaction between the two predictor variables graphically. In monistic contexts, a higher share of asylum seekers is associated with fewer claims about voiceless groups (bottom-left of Figure 2). In this case, we seem to observe a situation as the share of voiceless groups increases, it becomes more difficult to single them out: Administrative categories are likely to be considered more adequate or natural to refer to these immigrants. By contrast, in pluralistic contexts, there are more claims about voiceless groups where the share of asylum seekers is larger (top-right of Figure 2). In this case, we seem to observe a situation where voiceless groups are increasingly singled out as their share in the population increases: In contexts where many ways to refer to immigrant groups have currency, there are reasons not to politicize asylum seekers. In sum, it appears that the character of citizenship regimes and their influence on politicization come to the fore especially when the share of voiceless groups increases.
Figure 2: Claims about Voiceless Groups and Citizenship Regime

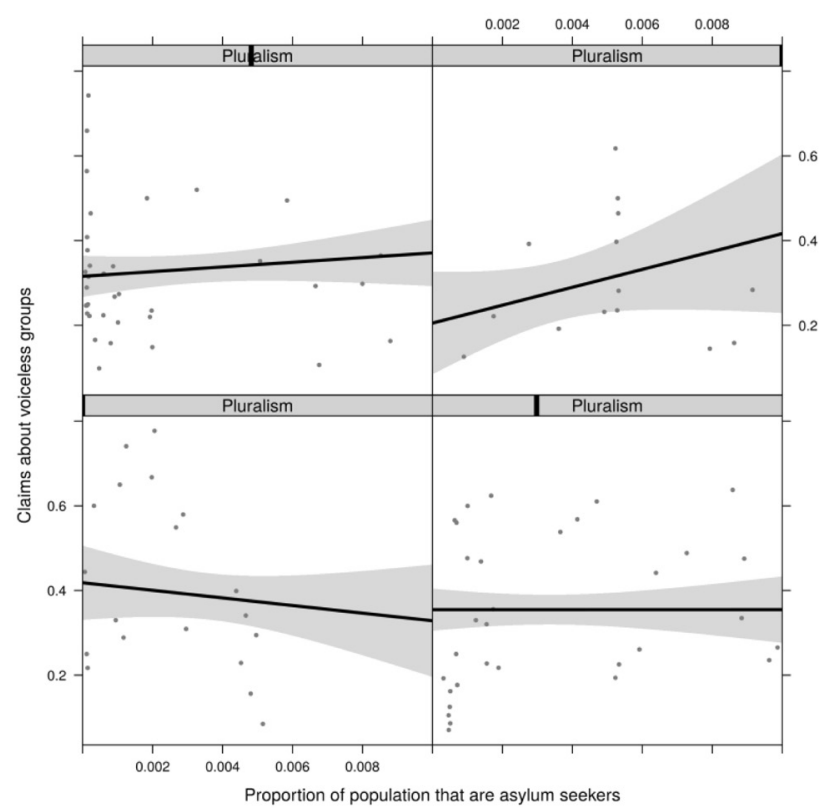

Notes: outcome variable: proportion of claims that are about voiceless groups; predictor variables: share of asylum seekers in the population, citizenship regime (monistic-pluralistic). The dark stripe indicates the relative level of pluralism: lowest in the bottom-left panel, and highest in the topright panel. Only shares of asylum seekers $<\mathrm{I} \%$ of the population are shown to avoid misleading extrapolations due to a small number of observations.

\section{Discussion}

While countries across Western Europe are all affected by immigration, the political debate on immigration and the civic integration of immigrants varies across countries. In this article, I argue that the way the debate on immigration is carried out depends on specific actorobject constellations and in particular the citizenship regime. The politicization of different immigrant groups is not merely a reflection of group size in the population. Immigrant groups unlikely to fend for themselves are likely to be politicized, irrespective of the fact that other groups like European immigrants are much more numerous. Contrary to the expectation, claims about voiceless groups are not generally more negative than claims about other immigrant groups. Civil-society organizations and left-wing parties tend to make positive claims about voiceless groups, but this is a reflection of their generally more positive stance on immigration. Voiceless groups are thus present in the debate on immigration and integration mostly as objects: talked about, debated, but shaped by others (see Berkhout/Ruedin 2016 for a similar observation on Muslim immigrants). While this does not seem to affect the tone of the debate as such, this article shows that the justifications used in 
claims about voiceless groups are different: Normative arguments such as human rights are more common, as are claims that invoke identity, compared to claims with instrumental justifications. This indicates that voiceless groups as objects of the debate are used for symbolic politics more often than immigrants in general, perhaps with the exception of Muslims. Put differently, while immigration may generally play an important role in identity politics and boundary making, it is in particular voiceless groups that are referred to.

This article highlights that citizenship regimes reflect the bounds in which the debate on immigration takes place. With the data at hand it is impossible to disentangle causality in a definitive manner: whether citizenship regimes set the bounds, or whether both the debate and citizenship regimes are influenced by common underlying factors. What the article could show, howev$\mathrm{er}$, is that the kind of debate that takes place in different contexts varies: Depending on the citizenship regime, different arguments are put forward, like the relatively more frequent use of instrumental frames in more civic contexts. Depending on the citizenship regime in place, the politicization of voiceless groups is also affected - in contexts with more ethnic and monistic citizenship regimes, voiceless groups are politicized more frequently than in more civic and pluralistic contexts. The citizenship regime thus crystallizes as a covariate for differences in the politicization of immigration across time and countries. Put differently, because of differences in the citizenship regime - being more ethnic or civic, being more pluralistic or monistic -, different reactions and different forms of politicization can be expected even when the situation on the ground otherwise seems alike. Future research should pay attention to the potential politicization of (recent) refugees as Muslims (compare Berkhout/Ruedin 2016).

The differences in frames and in the number of claims about voiceless immigrant groups reported here may point to wider differences in the style of the debate. When a political actor makes a claim about an immigrant group, he or she has a choice how individuals are identified, be this in terms of legal status, religion, or a different criteria. While in some contexts claimants may be more likely to choose an ethnic label, in different contexts they may focus on legal status to refer to the very same group. The analysis in this article suggests that the choice of how immigrants are referred to in claims in the news - and how they are ultimately constituted and boundaries are constructed - correlates with the citizenship regime in place, just as it does with actorobject constellations. It is in this sense that it is possible to speak of the citizenship regime shaping the debate. More research is needed to understand how the citizenship shapes the association between population size and politicization of immigrant groups - in the manner ini- tiated in this article. These interaction effects are important for understanding how citizenship regimes reflect the bounds of the political debate on immigration and integration.

More research and theory is also needed to explore whether the two dimensions outlined by Koopmans et al. (2005) are the most suited for understanding differences in politicization. With seven countries included, it is impossible to rule out that case selection affects the results in this article. For instance, the politicization of asylum seekers is common in Ireland while it is almost absent in the other 'new' immigration country in the sample: Spain (Van der Brug et al. 2015). To some extent these concerns are alleviated by regarding citizenship regimes as tendencies rather than fixed properties of countries.

\section{Conclusion}

This article has examined the politicization of immigrant groups in seven Western European countries, drawing on data from a large-scale claims analysis. Using the analytical category of voiceless groups - asylum seekers, refugees, irregular immigrants, groups with considerable residence insecurity and without access to formal franchise - the article demonstrated that claims about immigrants vary according to actor-object constellations and that the citizenship regime plays and important role in understanding differences in politicization across time and countries. Put differently, patterns of politicization are not entirely idiosyncratic or countryspecific. The politicization of immigrant groups is not a simple reaction to groups that may be rejected for being (perceived) threats to the majority population (compare Pecoraro/Ruedin 2016). It seems reasonable to assume that a certain number of immigrants from a particular group need to be present for them to be politicized, but beyond a very low threshold numbers are clearly not decisive for politicization. There does not appear to be a direct relationship between group size and the extent to which immigrant groups are politicized, yet the citizenship regime shapes how this relationship is borne out.

The findings on patterns of politicization contribute to critical reflections on the prospects of basic rights and democratic inclusion in societies with a significant number of immigrants in precarious situations (Beckman 20I3); they can provide the necessary foundations for theory-building. With regard to actor-object constellations, this article identified clear differences as to how different political actors politicize immigrant groups. While governments and centre-right parties are the source of positive and negative claims about immigrants - including voiceless groups, left-wing parties and civil-society organizations are the source of almost 
exclusively positive claims about immigrants. In this sense the immigrant groups referred to as voiceless are not completely voiceless - they have civil-society organizations to make claims on their behalf (Giugni/Passy 200I; Rosenberger/Ruedin 20I7).

Using a fine-grained approach drawing on Koopmans et al. (2005), it was possible to show that the politicization of immigration varies by citizenship regime. Further research is needed to strengthen the associations sketched here, reflect them in theory, and test them on fresh data. There are more claims about voiceless groups in ethnic (rather than civic) contexts, and in these ethnic contexts claims about voiceless groups are more likely to draw on normative principles as justifications. This article thus refines the argument by Helbling (2014) who found no association between citizenship regimes and frames used by political parties for specific immigrant groups. Not only are citizenship regimes related to which immigrant groups are more politicized, but also they are associated with how voiceless groups are referred to in political claims. In other words, citizenship regimes reflect the bounds within which debates on immigration and immigrant groups are held. In all constellations of citizenship regimes covered in this article, immigrant groups are politicized, but there are differences as to which groups are politicized more often and how these groups are referred to in political claims. Future research should address in more detail how citizenship regimes affect and are reflected in the political debate on immigration - and how that debate affects presumably also other minority groups in society.

\section{Literature}

Beckman, Ludvig (20I3). Irregular migration and democracy: the case for inclusion, in: Citizenship Studies, Vol. I7(I), 48-60.

Berkhout, Joost/Didier Ruedin (2016). Why Religion? Immigrant Groups as Objects of Political Claims on Immigration and Civic Integration in Western Europe, 1995-2009, in: Acta Politica, Early View.

Bleich, Erik/Irene Bloemraad/Els de Graauw (2015). Migrants, Minorities and the Media: Information, Representations and Participation in the Public Sphere, in: Journal of Ethnic and Migration Studies, Vol. $4 \mathrm{I}(6), 857-873$.

Bloemraad, Irene/Els de Graauw/Rebecca Hamlin (2015). Immigrants in the Media: Civic Visibility in the USA and Canada, in: Journal of Ethnic and Migration Studies, Vol. 4I(6), 874-896.

Brubaker, Rogers (2013). Categories of analysis and categories of practice: a note on the study of Muslims in European countries of immigration, in: Ethnic and Racial Studies, Vol. 36(I), I-8.
Cağlar, Ayse/Sebastian Mehling (2013). Sites and the scales of the law: third-country nationals and EU Roma citizens, in: Engin F. Isin/Michael Saward (eds.): Enacting European Citizenship, 155-77.

Caviedes, Alexander (2015). An Emerging 'European' News Portrayal of Immigration?, in: Journal of Ethnic and Migration Studies, Vol. 4I(6), 897-917.

Coenders, Marcel/Marcel Lubbers/Peer Scheepers (2013). Resistance to immigrants and asylum seekers in the European Union: Cross-national comparisons of public opinion, in: Gary P. Freeman/Randall Hansen/ David L. Leal (eds.): Immigration and Public Opinion in Liberal Democracies.

Constant, Amelie F./Martin Kahanec/Klaus F. Zimmermann (2009). Attitudes towards immigrants, other integration barriers, and their veracity, in: International Journal of Manpower, Vol. 30(I/2), 5-I4.

Ersanilli, Evelyn/Ruud Koopmans (2OII). Do Immigrant Integration Policies Matter? A Three-Country Comparison among Turkish Immigrants, in: West European Politics, Vol. 34(2), 208-234.

Finotelli, Claudia/Ines Michalowski (2012). The Heuristic Potential of Models of Citizenship and Immigrant Integration Reviewed, in: Journal of Immigrant \& Refugee Studies, Vol. IO(3), 23I-240.

Gibney, Matthew J. (2009). Precarious Residents: Migration Control, Membership and the Rights of NonCitizens, in: UNDP Human Development Reports Research Paper, Vol. Io.

Giugni, Marco/Florence Passy (eds.) (200I). Political Altruism? Solidarity Movements in International Perspective, Lanham.

Goldin, I./G. Cameron/M. Balarajan (201I). Exceptional People: How Migration Shaped Our World and Will Define Our Future, Oxford.

Helbling, Marc (2014). Framing Immigration in Western Europe, in: Journal of Ethnic and Migration Studies, Vol. 4O(I), 2I-4I.

Huddleston, Thomas/J. Niessen (20II). Migrant Integration Policy Index, Brussels: British Council and Migration Policy Group.

Klingeren, Marijn van/Hajo G. Boomgaarden/Rens Vliegenthart/Claes H. de Vreese (2015). Real World is Not Enough: The Media as an Additional Source of Negative Attitudes Toward Immigration, Comparing Denmark and the Netherlands, in: European Sociological Review, Vol. 3I(3), 268-283.

Koopmans, Ruud/Ines Michalowski (20I7). Why Do States Extend Rights to Immigrants? Institutional Settings and Historical Legacies Across 44 Countries Worldwide, in: Comparative Political Studies, Vol. 5O(I), $4 \mathrm{I}-74$.

Koopmans, Ruud/Ines Michalowski/Stine Waibel (2012). Citizenship rights for immigrants: National political processes and cross-national convergence in West- 
ern Europe, 1980-2008, in: American Journal of Sociology, Vol. II7(4), I2O2-I245.

Koopmans, Ruud/Paul Statham/Marco Giugni/Florence Passy (2005). Contested Citizenship: Immigration and Cultural Diversity in Europe, Minneapolis.

Korkut, Umut/Gregg Bucken-Knapp/Aidan McGarry/Jonas Hinnfors/et al. (2013). The Discourses and Politics of Migration in Europe, New York.

Krzyżanowski, Michał/Ruth Wodak (2009). The politics of exclusion: debating migration in Austria, New Brunswick.

Kymlicka, Will (20II). New directions and issues for the study of ethnicity, nationalism and multiculturalism, in: Ethnicities, Vol. II(I), 5-II.

Lawlor, Andrea (2015). Local and National Accounts of Immigration Framing in a Cross-national Perspective, in: Journal of Ethnic and Migration Studies, Vol. 4I(6), 9I8-94I.

Meyer, Sarah/Sieglinde Rosenberger (2015). Just a Shadow? The Role of Radical Right Parties in the Politicization of Immigration, 1995-2009, in: Politics and Governance, Vol. 3(2), I-I7.

Morales, Laura/Virgina Ros/Laura Sudulich/Joost Berkhout/ et al. (2012). Comparative Data Set of ImmigrationRelated Statistics 1995-2009 [Data File], IQSS Dataverse, available at: http://hdl.handle.net/1902.I/17963 (accessed 02.09.2016).

Park, K. (2014). Foreigners or multicultural citizens?: Press media's construction of immigrants in South Korea, in: Ethnic and Racial Studies, Vol. 37(9), I565-I586.

Pecoraro, Marco/Didier Ruedin (2016). A Foreigner Who Does not Steal My Job: The Role of Unemployment Risk and Values in Attitudes toward Equal Opportunities, in: International Migration Review, Vol. 5O(3), 628-666.

Revelle, William (2015). psych: Procedures for Psychological, Psychometric, and Personality Research, Evanston, Illinois: Northwestern University, available at: http://CRAN.R-project.org/package=psych (accessed O2.09.2016).

Rosenberger, Sieglinde/Didier Ruedin (2017 forthcoming). The Politicization of Asylum Seekers and Other Immigrant Groups in a Comparative Perspective, in: Merli, Franz/Pöschl, Magdalena (eds.): Asylrecht als Experimentierfeld, Vienna.

Ruedin, Didier (2015). Increasing Validity by Recombining Existing Indices: MIPEX as a Measure of Citizenship Models, in: Social Science Quarterly, Vol. 96(2), 629-638.

Ruedin, Didier (20I3). MIPEX Over Time Data: Detailed [Data File], IQSS Dataverse, available at: http://hdl. handle.net/1902.I/20529 (accessed 02.09.2016).
Ruedin, Didier/Sieglinde Rosenberger/Nina Merhaut (2017 forthcoming). Tracing Anti-Deportation Protests: A Longitudinal Comparison of Austria, Germany, and Switzerland, in: Sieglinde Rosenberger (ed.): Comparative Analysis of Protest Movements in Refugee, Asylum and Deportation Policies, New York.

Schuster, Liza (2003). The Use and Abuse of Political Asylum in Britain and Germany, London.

Squire, Vicki (2009). The Exclusionary Politics of Asylum, Basingstoke.

Tholen, Berry (2009). Privileging the near and dear? Evaluating special ties considerations in EU migration policy, in: Ethnicities, Vol. 9(I), 32-52.

Van der Brug, Wouter/Gianni D'Amato/Joost Berkhout/ Didier Ruedin, (eds.) (2015). The Politicisation of Migration, Abingdon.

Vasta, E. (2OIO). The controllability of difference: Social cohesion and the new politics of solidarity, in: Ethnicities, Vol. IO(4), 503-521.

Vink, Maarten Peter/Rainer Bauböck (2013). Citizenship configurations: Analysing the multiple purposes of citizenship regimes in Europe, in: Comparative European Politics, Vol. II(5), 62 I-648.

de Wilde, Pieter (2007). Politicisation of European Integration: Bringing the Process into Focus, in: University of Oslo ARENA Working Paper, Vol. 18, I-34.

Zincone, G./R. Penninx/M. Borkert (eds.) (20II). Migratory Policymaking in Europe: The Dynamics of Actors and Contexts in Past and Present, Amsterdam.

\section{Author}

Didier Ruedin (DPhil, Oxford; born 1979) is a project officer and lecturer at the Swiss Forum for Migration and Population Studies at the University of Neuchâtel, Switzerland, and a Visiting Research Fellow at the African Centre for Migration \& Society at the University of the Witwatersrand, South Africa. His research focuses on reactions to immigration and diversity: attitudes towards immigrants and the politicization of immigration. Recent publications include: Zschirnt, Eva and Didier Ruedin. 2016. "Ethnic discrimination in hiring decisions: A meta-analysis of correspondence tests 1990-2015", Journal of Ethnic and Migration Studies, 42(7):1115-34. 


\section{Appendix}

\section{Appendix A1: Citizenship Regimes}

Citizenship regime on the ethnic-civic and monistic-pluralistic dimensions following Ruedin (2015), with the mean and range of values between 1995 and 2009 to highlight the dynamic nature of citizenship regimes.

\begin{tabular}{lllllll}
\hline Country & Ethnic-Civic & & \multicolumn{3}{c}{ Monistic-Pluralistic } \\
& mean & $\min$ & $\max$ & mean & $\min$ & max \\
\hline Austria & 34 & 29 & 41 & 36 & 19 & 51 \\
Belgium & 61 & 51 & 77 & 63 & 55 & 75 \\
Ireland & 59 & 40 & 76 & 43 & 33 & 60 \\
Netherlands & 73 & 72 & 76 & 80 & 61 & 85 \\
Spain & 41 & 26 & 52 & 66 & 57 & 72 \\
Switzerland & 43 & 40 & 47 & 46 & 37 & 49 \\
United Kingdom & 62 & 56 & 75 & 50 & 41 & 52 \\
\hline
\end{tabular}

Appendix A2: Newspaper Coverage

\begin{tabular}{ll}
\hline Country & Newspapers \\
\hline Austria & Der Standard, Neue Kronen Zeitung \\
Belgium & De Standaard, Le Soir; Het Laatste Nieuws, La Dernière Heure \\
Ireland & The Irish Times, Irish Daily Star \\
Netherlands & Volkskrant, Telegraaf \\
Spain & El País, La Vanguardia \\
Switzerland & Neue Zürcher Zeitung, Blick; Le Temps/Tribune de Genève, Le Matin \\
United Kingdom & The Guardian, Daily Mail \\
\hline
\end{tabular}

\section{Appendix A3: Frames}

Basic coding scheme for frames, for the full codebook including sub-frames, refer to Van der Brug et al. (2OI5).

\begin{tabular}{ll}
\hline $\begin{array}{l}\text { Frame } \\
\text { No argument } \\
\text { Instrumental }\end{array}$ & Definition \\
Identity & $\begin{array}{l}\text { Arguments about collective identity (i.e. nationality), ethics, values, community, culture and } \\
\text { appropriateness } \\
\text { Moral principles }\end{array}$ \\
\hline
\end{tabular}


Appendix A4: Actor Classifications

\begin{tabular}{|c|c|c|c|c|}
\hline \multirow[t]{2}{*}{ Country } & \multicolumn{2}{|c|}{ Anti-Immigrant Parties } & \multicolumn{2}{|l|}{ Left-Wing Parties } \\
\hline & Party & Party ID & Party & Party ID \\
\hline \multirow[t]{2}{*}{ Austria } & FPÖ & 42420 & Grüne & 42110 \\
\hline & BZÖ & 42710 & SPÖ & 42320 \\
\hline \multirow[t]{4}{*}{ Belgium } & VB & 21914 & Ecolo & 21111 \\
\hline & $\mathrm{FN}$ & 21710 & Groen (Agalev) & 21112 \\
\hline & & & SP/ SP.A & 21221 \\
\hline & & & PS & 21322 \\
\hline \multirow[t]{5}{*}{ Ireland } & $\mathrm{n} / \mathrm{a}$ & & Green Party & 53110 \\
\hline & & & Democratic Left & 53221 \\
\hline & & & Labour Party & 53320 \\
\hline & & & Sinn Fein & 53951 \\
\hline & & & Socialist Party & 53999 \\
\hline \multirow[t]{4}{*}{ Netherlands } & PVV & 22722 & $\mathrm{GL}$ & 22110 \\
\hline & LPF & 22720 & SP & 22220 \\
\hline & & & PvdA & 22320 \\
\hline & & & PvdD & 22951 \\
\hline \multirow[t]{3}{*}{ Spain } & $\mathrm{n} / \mathrm{a}$ & & IU & 33220 \\
\hline & & & PSOE & 33320 \\
\hline & & & BNG & 33908 \\
\hline \multirow[t]{3}{*}{ Switzerland } & SVP & 43810 & Grüne & 43110 \\
\hline & SD & 43710 & $\mathrm{SP}$ & 43320 \\
\hline & FP/AP & 43951 & FDP & 43420 \\
\hline \multirow[t]{2}{*}{ United Kingdom } & UKIP & 51951 & Labour Party & 51320 \\
\hline & BNP & 51701 & & \\
\hline
\end{tabular}


